\title{
ANALISA DAN DESAIN INTEGRASI DATA PENDIDIKAN KOTA PEKALONGAN
}

\author{
Christian Yulianto Rusli, Muhammad Faizal Kurniawan, Wahyu Setianto \\ Program Studi Teknik Informatika \\ STMIK Widya Pratama, Jl. Patriot 25, Pekalongan \\ Korespondensi: cyr.tata@yahoo.com
}

\begin{abstract}
The Education Office of Pekalongan City has the duty and authority to regulate the implementation policy and education service in Pekalongan city. In carrying out its duties the education office needs to take appropriate policies to ensure the implementation of education services in the city of Pekalongan more qualified. In terms of policy making, of course the Education Office requires actual and valid data that can inform the state of Pekalongan City, especially related to education services. The availability of this data is a constraint faced by the Education Office, because the data needed spread. For schoolrelated data, the Education Office has been working with the Ministry of Education of the Republic of Indonesia, where currently DAPODIKDASMEN replication server is available at the Education Office of Pekalongan City. However, the data available in this DAPODIKDASMEN system still needs to be collaborated with poverty data and population data which currently kominfo Pekalongan City has access rights. In addition there is also Individual Report data obtained directly from schools. Through this research, it is proposed an integrated system of education data of Pekalongan City which is the result of collaboration between DAPODIKDASMEN, poverty data, population data and individual reports. In the development of the Research use the Linear Sequential method to ensure the stages are done quite clearly. The resulting designs include system infrastructure design and required database design.
\end{abstract}

Keywords : DAPODIKDASMEN, integration, database, education

\begin{abstract}
ABSTRAK
Dinas Pendidikan Kota Pekalongan memiliki tugas dan wewenang untuk mengatur kebijakan penyelenggaraan serta pelayanan pendidikan di kota Pekalongan. Dalam menjalankan tugasnya dinas pendidikan perlu mengambil kebijakan-kebijakan yang tepat guna menjamin terselenggaranya pelayanan Pendidikan di Kota Pekalongan yang makin bermutu. Dalam hal pengambilan kebijakan, tentunya Dinas Pendidikan membutuhkan data yang aktual dan valid yang dapat menginformasikan keadaan Kota Pekalongan khususnya yang berkaitan dengan pelayanan pendidikan. Ketersediaan data inilah yang menjadi kendala yang dihadapi oleh Dinas Pendidikan, karena data yang dibutuhkan tersebar. Untuk data yang berkaitan dengan sekolah Dinas Pendidikan telah bekerjasama dengan Kementrian Pendidikan Republik Indonesia, dimana saat ini telah tersedia server replikasi DAPODIKDASMEN yang terinstall di Dinas Pendidikan Kota Pekalongan. Namun, data yang ada disistem DAPODIKDASMEN ini masih perlu dikolaborasi dengan data kemiskinan dan data penduduk Kota Pekalongan yang saat ini hak aksesnya ada di Kominfo Kota Pekalongan. Selain itu juga ada data Laporan Individu yang didapat langsung dari sekolah-sekolah. Melalui penelitian ini diusulkan sebuah sistem terintegrasi
\end{abstract}


data kependidikan Kota Pekalongan yang merupakan hasil kolaborasi antara DAPODIKDASMEN, data kemiskinan, data penduduk dan laporan individu. Dalam pengembangannya Penelitian menggunakan metode Sekuensial Linier untuk memastikan tahap-tahap terlaksana dengan cukup jelas. Desain yang dihasilkan meliputi desain infrastruktur sistem dan desain database yang diperlukan.

Kata Kunci: DAPODIKDASMEN, integrasi, database, pendidikan

\section{PENDAHULUAN}

Penerapan teknologi informasi dalam wujud sistem informasi memberikan kemudahan bagi penggunanya baik dalam hal pengisian data, kebutuhan data dalam pelaporan maupun dalam pengambilan kebijakan. Pemerintah kota Pekalongan telah menerapkan sistem informasi untuk menunjang proses pelayanan pada masyarakat. Salah satu Organisasi Perangkat Daerah (OPD) di pemerintahan kota Pekalongan yang telah menerapkan sistem informasi tersebut adalah Dinas Pendidikan. Dinas pendidikan kota Pekalongan tidak sekedar membawahi jenjang sekolah dasar dan menengah saja melainkan seluruh jenjang pendidikan baik formal maupun nonformal.

Salah satu misi pembangunan 2016-2021 Kota Pekalongan yaitu meningkatkan akses dan mutu pendidikan masyarakat Kota Pekalongan. Misi tersebut tentunya secara teknis dilaksanakan oleh Dinas Pendidikan Kota Pekalongan. Namun, Dinas Pendidikan Kota Pekalongan dalam pengambilan kebijakan masih dilakukan secara manual, dimana data didapat dari pihak sekolah-sekolah. Pada kenyataannya sekolah sudah menggunakan sistem Data Pokok Pendidikan Dasar dan Menengah (DAPODIKDASMEN) yang merupakan sumber data utama pendidikan tingkat dasar dan menengah nasional dan merupakan bagian dari program perencanaan pendidikan nasional dalam mewujudkan insan Indonesia yang cerdas dan kompetitif. Dimana tiap sekolah memiliki akun masing-masing yang digunakan untuk melaporkan data pendidikan ditiap sekolah kepada kementerian pendidikan.

Permasalahan yang dihadapi oleh dinas pendidikan kota Pekalongan adalah data yang dilaporkan oleh sekolah melalui DAPODIKDASMEN merupakan data yang otoritasnya dimiliki oleh Kementerian Pendidikan. Dinas pendidikan hanya dapat menampilkan data secara sistem yang telah diolah oleh sistem DAPODIKDASMEN. Hal ini menyebabkan Dinas Pendidikan Kota Pekalongan kesulitan dalam pengolahan data lebih lanjut untuk kepentingan pengambilan kebijakan dan pelaporan. Selain itu pada kenyataannya Dinas Pendidikan Kota Pekalongan tidak hanya membutuhkan data di tingkat dasar dan menengah, namun seluruh data berkaitan dengan pendidikan dari mulai dasar, menengah hingga tingkat tinggi termasuk juga pendidikan nonformal. Dari sisi kelengkapan data propinsi Jawa Tengah menempati posisi pertama dengan nilai indeks kelengkapan data rata-rata sebesar $80,37 \%$, sedangkan di tingkat propinsi Jawa Tengah terdapat 35 kab./kota, peringkat Kota Pekalongan menempati peringkat 35 dengan nilai indeks kelengkapan data rata-rata sebesar 69,35\% pada semester genap 2016/2017.

Adanya pelaporan tiap jenjang sekolah kepada kementerian pendidikan baik itu jenjang sekolah dasar, menengah maupun perguruan tinggi yang dilakukan oleh 
masing-masing sekolah melalui direktorat jendral pendidikan sesuai jenjang pendidikannya menyebabkan Dinas Pendidikan Kota Pekalongan kesulitan dalam mengolah data untuk pengabilan kebijakan. Dengan demikian alangkah lebih baik apabila data-data tersebut juga dimiliki oleh Dinas Pendidikan Kota Pekalongan sehingga memudahkan bagi pengolahan data untuk kepentingan pengambilan kebijakan demi meningkatkan akses dan kualitas pendidikan masyarakat Kota Pekalongan.

Berdasarkan kendala-kendala oleh Dinas Pendidikan Kota Pekalongan, maka melalui Riset Unggulan Daerah ini akan diusulkan model integrasi sistem kependidikan di Kota Pekalongan. Harapannya dengan adanya rancangan yang diusulkan dapat mempermudah terwujudnya integrasi sistem kependidikan di Kota Pekalongan. Rancangan yang diusulkan meliputi rancangan infrastruktur dan rancangan database.

\section{LANDASAN TEORI}

\subsection{Basis Data}

Basis data adalah sekumpulan data store (bisa dalam jumlah yang sangat besar) yang tersimpan dalam media peyimpanan sekunder. Basis data adalah sekumpulan program-program aplikasi umum yang bersifat batch yang mengeksekusi dan memproses data secara umum (seperti: pencarian, peremajaan, penambahan dan penghapusan terhadap data). (B., 2004)

\subsection{DBMS}

DBMS adalah koleksi terpadu dari database dan program-program komputer (utilitas) yang digunakan untuk mengakses dan memelihara database (B., 2004). Program-program tersebut menyediakan berbagai macam fasilitas operasi untuk memasukkan, melacak dan memodifikasi data ke dalam database, mendefinisikan data baru serta mengolah data menjadi informasi yang dibutuhkan atau dengan kata lain DBMS = DATABASE + PROGRAM UTILITAS (AI-Bahra, 2004). DBMS itu yang umum dipakai diantaranya adalah MySQL, PostgreSQL, Oracle, Access, dan lain-lain

\subsection{Basis data terdistribusi}

Basis data terdistribusi adalah kumpulan data logic yang saling berhubungan, secara fisik terdistribusi dalam jaringan komputer, yang tidak tergantung dari program aplikasi dan dapat digunakan oleh banyak aplikasi sekarang maupun pada masa yang akan datang. (B., 2004)

\subsection{DBMS terdistribusi}

DBMS Terdistribusi adalah sebuah perangkat lunak yang membuat pendistribusian data dan memberikan mekanisme akses data yang akan membuat basis data ini transparan kepada user yang menggunakan. (B., 2004)

\subsection{Data Integrasi}

Data Integration atau integrasi data merupakan proses menggabungkan atau menyatukan dua atau lebih sebuah data dari berbagai sumber database yang berbeda ke dalam sebuah penyimpanan seperti gudang data (data warehouse) (Anonim, 2017) 


\subsection{Web Service}

Menurut (Babin, 2007), web service dirancang agar komputer dengan perangkat lunak berbeda dan pada jaringan berbeda dapat berkomunikasi dengan mudah satu sama lain dalam lingkungan lintas platform (biasanya $\mathrm{XML}$ ). Web Service menjadi alat yang penting didalam penyedia layanan seperti Google, PayPal, Amazon, eBay bahkan di Indonesia banyak penyedia layanan sudah menggunakan web service, sebut saja RajaOngkir yang menyediakan layanan informasi ongkos kirim dari berbagai kurir di Indonesia.

\section{METODE PENGUMPULAN DATA}

Metode pengumpulan data untuk mengetahui kebutuhan integrasi database pendidikan Kota Pekalongan adalah dengan menggunakan metode studi literatur dan wawancara. Wawancara dilakukan dengan pihak terkait yaitu Dinas Pendidikan, Dinas Komunikasi dan Informatika, Dinas Kependudukan dan Pencatatan Sipil serta Kementerian Pendidikan dan Kebudayaan

\subsection{Wawancara}

Wawancara dilakukan dengan narasumber yang terkait dengan penelitian, yaitu Dinas Pendidikan Kota Pekalongan, Dinas Kependudukan dan Pencatatan Sipil Kota Pekalongan, Dinas Komunikasi dan Informatika serta Kementerian Pendidikan dan Kebudayaan.

\subsection{Studi Literatur}

Studi literatur dilakukan terhadap bebrapa peraturan terkait dengan penerapan data-data yang dibutuhkan antara lain Peraturan Menteri Dalam Negeri No. 61 Tahun 2015 tentang Persyaratan Ruang Lingkup dan Tata Cara Pemberian Hak Akses serta Pemanfaatan Nomor Induk Kependudukan, Data Kependudukan dan Kartu Tanda Penduduk Elektronik.

\section{HASIL DAN PEMBAHASAN}

\subsection{Hasil Analisis Data}

Setelah melakukan analisis terhadap hasil wawancara, hasil studi literature, maka dapat diidentifikasi permasalahan yang ada serta kebutuhan yang harus dipenuhi dalam sistem yang akan dibangun.

4.1.1 Identifikasi Permasalahan

Berikut ini adalah beberapa permasalahan yang sudah dapat diidentifikasi, yaitu:

- Dinas Pendidikan membutuhan data dalam menentukan kebijakan pendidikan kota Pekalongan, data yang dibutuhkan merupakan data lintas sektoral;

- Adanya aturan di Kementerian Dalam Negeri yang mengatur pengunaan dan hak akses data kependudukan;

- Beberapa kebutuhan data dari DINDUKCAPIL tidak dapat diperoleh menggunakan MANTRA;

- DBMS yang digunakan tiap database yang dimiliki oleh OPD berbedabeda; 
- Server database secara fisik berada dibeberapa lokasi yang berbeda;

- Dinas Pendidikan masih menggunakan Laporan Individu (LI) untuk verifikasi validitas DAPODIK dari tiap satuan pendidikan.

4.1.2 Identifikasi Kebutuhan

- Perlu adanya bridging system untuk menjembatani beberapa database yang berbeda;

- Tersedianya informasi yang terkini tentang kondisi pendidikan kota Pekalongan;

- Tersedianya informasi data kemiskinan warga kota Pekalongan yang terbarui;

- Perlu adanya kemudahan didalam pengolahan data laporan individu.

- Perlu adanya sebuah sistem yang mampu mengolah kebutuhan data dari DINDUKCAPIL yang tidak dapat diperoleh melalui MANTRA.

\subsubsection{Solusi}

Dari identifikasi tersebut, maka solusi yang diperlukan adalah desain infrastruktur dan database yang dapat mengintegrasikan beberapa data dari OPD yang berbeda database dan lokasi.

\subsection{Desain Sistem}

4.2.1 Desain Infrastruktur

Melihat dari pengumpulan data dan hasil analisis, maka didapatkan desian infrastruktur ada 2 alternatif yaitu :

a. Alternatif 1

Pada alternatif pertama dalam desain ini mempertimbangkan visi dan misi pemerintah kota Pekalongan yang ingin mewujudkan satu database. Dalam implementasi secara fisik, penerapan satu database ini tidak dapat secara menyeluruh diterapkan dalam satu organisasi perangkat desa (OPD). Hal ini disebabkan adanya Peraturan Kementerian Dalam Negeri No. 16 tahun 2015 tentang Persyaratan Ruang Lingkup dan Tata Cara Pemberian Hak Akses serta Pemanfaatan Nomor Induk Kependudukan, Data Kependudukan dan Kartu Tanda Penduduk Elektronik. 


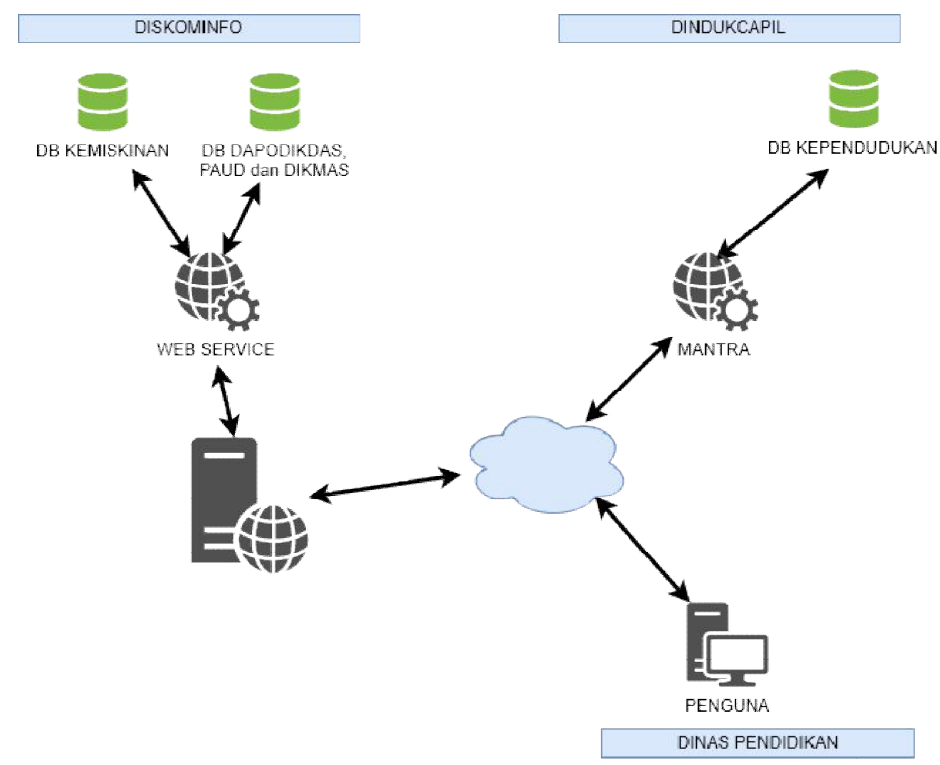

Gambar 1 Desain Infrastruktur Alternatif 1

b. Alternatif 2

Pada alternatif kedua ini mempertimbangkan bahwa DAPODIK sudah tersedia pada DINDIK melalui Kementerian Pendidikan dan Kebudayaan, disamping itu DINDIK juga masih harus melakukan verifikasi ulang terhadap data DAPODIK dari tiap satuan pendidikan. Verifikasi ini dimaksudkan sebagai validasi terhadap data yang diinputkan kedalam DAPODIK. Pada alternatif kedua in juga mempertimbangkan bahwa beberapa kebutuhan data yang terkait dengan DINDUKCAPIL tidak semuanya bisa diambil/diminta melalui MANTRA (hal ini terkait dengan regulasi dari Kementerian Dalam Negeri), sehingga beberapa data tersebut harus dimintakan secara manual kepada DINDUKCAPIL. Untuk mempermudah dalam mendapatkan data dari DINDUKCAPIL tersebut maka, disarankan untuk sekaligus dibuatkan kedalam database sehingga DINDUKCAPIL nantinya tinggal mengisi kedalam database tersebut.

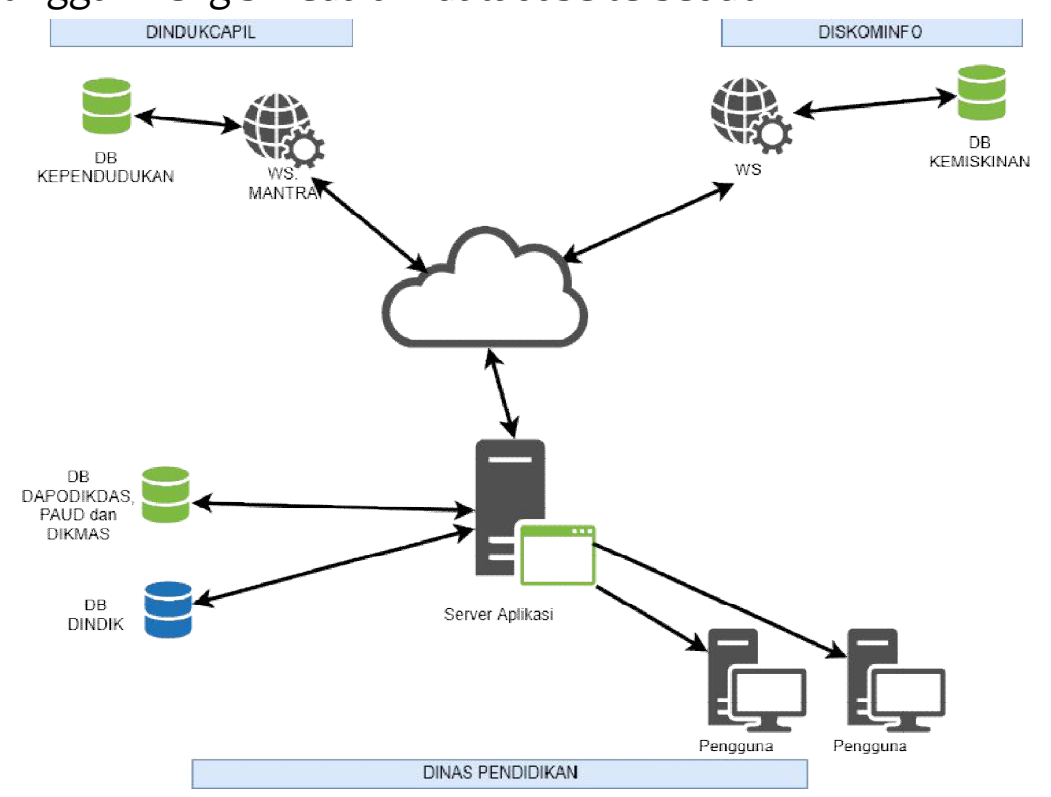

Gambar 2 Desain Infrastruktur Alternatif 2 


\subsubsection{Desain Database}

Penggambaran database menggunakan class diagram yang diharapkan dapat menggambarkan hubungan tiap entitas.

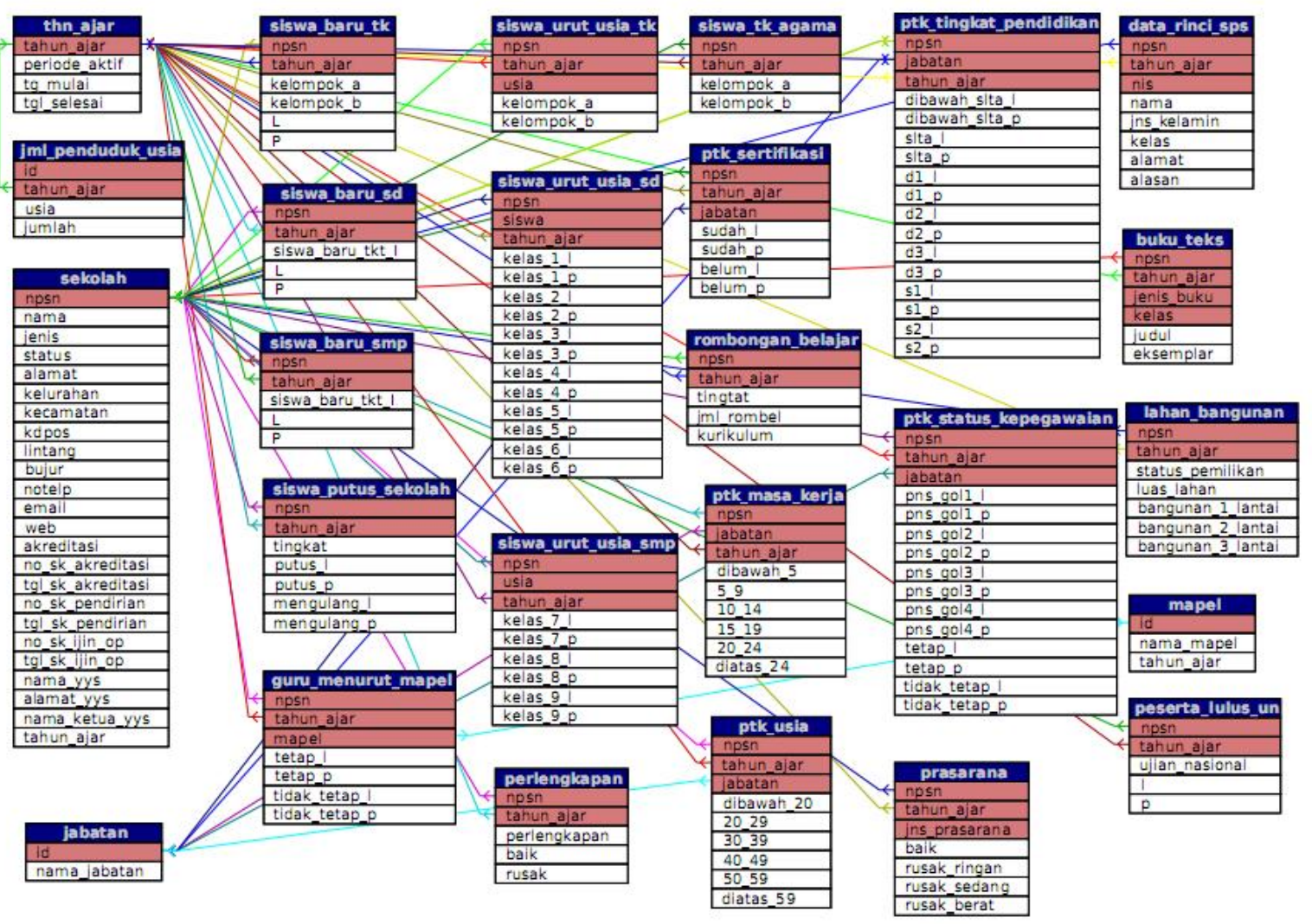

Gambar 3 Diagram Class

\section{PENUTUP}

Desain alternatif yang diusulkan adalah desain alternatif 2, dimana dengan desain infrastruktur ini Dinas Pendidikan dapat menerapkan data integrasi yang selaras dengan Permendagri No. 61 tahun 2015 dan sesuai pula dengan keadaan dimana DAPODIK sudah tersedia di Dinas Pendidikan. Disamping itu kebutuhan akan data kemiskinan dan data kependudukan dapat tersedia dengan adanya web services. Data kependudukan yang tidak dapat disediakan oleh web services dapat diperoleh dengan dibuatkan sebuah dashboard untuk diinput oleh Dinas Kependudukan. Demikian pula dengan laporan individu dimana data ini disimpan didalam database yang sama dan berada di Dinas Pendidikan.

\section{DAFTAR PUSTAKA}

Anonim. (2017, 12 7). Data Integration. Retrieved from https://www.softbless.com/Data-Integration

B., A.-B. B. (2004). Konsep Sistem Basis Data dan Implementasinya. Yogyakarta: Penerbit Graha IImu.

Babin, L. (2007). Beginning Ajax with PHP From Novice to Professional. New York: Apress. 
BPS. (2017, 04 04). Pendidikan. Retrieved from Badan Pusat Statistik: https://www.bps.go.id/Subjek/view/id/28

Departemen P dan K. (1984). Pengertian Pola. Jakarta: Departemen P\&K.

Pressman, R. S. (2010). Rekayasa Perangkat Lunak (Pendekatan Praktisi) Edisi 7 : Buku 1. Yogyakarta: Penerbit ANDI.

Simamarta, A. (1983). Operations Research: sebuah pengantar. Jakarta: PT. Gramedia. 